\title{
The urge to begin anew: Visions of America in some American long poems ${ }^{1}$
}

\author{
Tony Ullyatt \\ English Department \\ Free State University \\ BLOEMFONTEIN
}

\begin{abstract}
The urge to begin anew: Visions of America in some American long poems

The basic purpose of this article is to survey the visions of America embodied in a number of American long poems from different literary periods. Since there have been a considerable number of long poems written in America during its almost 350-year history, it has been necessary to make some stringent selections. The texts used here have been chosen for their literary-historical importance. Starting with Michael Wigglesworth's 1662 poem. The Day of Doom, the article proceeds to the work of Joel Barlow' and, to a lesser extent, Philip Freneau from the late eighteenth and early nineteenth centuries before approaching Walt Whitman's Leaves of Grass from the late nineteenth century, and Allen Ginsberg's poem, Howl, from the mid-rwentieth century.
\end{abstract}

\section{The urge to begin anew}

America has always felt compelled to seek an identity unique to itself where it can experiment with, and make optimum use of its existential possibilities as a place of new beginnings in time and space. As more and more explorations of space and time occurred, this quest became increasingly metaphorical. Nonetheless, there is a certain sense in which each age viewed itself as having that potential, that pristine newness, and this may serve to explain the urge of many poets throughout American literary history to provide their age with a representatively magisterial poem.

Voyages of discovery had given rise to descriptions and conceptualisations of the continent which were compounded by and embellished with classical myth and biblical analogy, as well as a good deal of unbridled imagination, to yield visions of unlimited possibilities and brute terror. In the beginning was faith and fear.

1 In my title, the phrase, "The urge to begin ancw", is Glauco Cambon's. 


\section{A palisade made from the jargon of God}

In a poem called "Uppon the first sight of New-England", Thomas Tillam (1968:

15) wrote:

hayle holy-land wherein our holy lord hath planted his most true and holy word hayle happy people who have dispossest your selves of friends, and meanes, to find some rest

for your poore wearied soules, opprest of late

for Jesus-sake, with Envye, spight, and hate

to yow that blessed promise truly's given

of sure reward, which you'll receve in heaven.

We note the complete absence in Tillam's account of any factual description of geographic features, local inhabitants, or indigenous flora and fauna, the new land being described simply as "holy". The religious tone of the piece provides a clear indication of the way in which the Puritans were going to cope with, or even overcome, any sense of ontological insecurity: they were going to substitute faith for fear.

Perhaps Tillam was more fortunate in his first views and perceptions of the newfound land than William Bradford, whose account of the landing of the Pilgrim Fathers (1985:31-32) contains a much more brutally realistic description of the settlers' situation. Tillam's articulations of the colony as a metaphor for a new holy land find no parallels in Bradford's realities. There were "no friends to welcome them or inns to entertain or refresh their weather-beaten bodies" - an observation which is strikingly silly if such were their expectations; instead, they were confronted by "savage barbarians" who, unlike their biblical counterparts, were less willing to "refresh" the new settlers but rather more willing to "fill their sides with arrows". Seeing nothing "but a hideous and desolate wilderness, full of wild beasts and wild men - and what multitudes there might be of them they knew not" and having to establish some sort of settlement during the "sharp and violent" inhospitalities of winter, Bradford rhetorically asks: "What could now sustain them but the Spirit of God and His Grace?" It was a question answered by Francis Higginson in New-Englands Plantation (1630) (1965:17):

That which is our greatest comfort, and meanes of defence above all others is, that we have here the true Religion and holy Ordinances of Almightie God taught amongst us ... thus we doubt not but God will be with us, and if God be with us, who can be against us?

Of course, the obvious and realistic reply - "the Red Indians" - seems to have eluded Higginson. The Puritan strategy for coping with what William Carlos 
Williams (1971:78) has called the "sufficient terror" of the "emptiness about them" was, he argues, "( $t$ )he jargon of God ... their dialect by which they kept themselves surrounded as with a palisade". They used this "jargon" to articulate their vision of rebuilding Zion, a vision that was so literal in Puritan thinking that they were readily able to unite biblical wilderness and the "hidious and desolate wilderness" of America by creating parallels between biblical Jew and colonial Puritan, Zion and colony, Old Testament battles and the slaughter inflicted by Red Indians. Crude colonial dwellings were transmogrified into a city set upon an hill, in the open view of all the earth while the battle between God and Satan occurred daily as sin and temptation brought every believer to regular choices between good and evil.

Setting out to rebuild the Holy City of Zion, the Puritans sought conformity and unanimity from communities through the power of the doctrine of predestination. Indeed, the rebuilding of the City of Zion depended a good deal less on love and compassion than it did on other and more evil means. Adopting a sadomasochistic attitude towards sinners, the Puritans used brute cruelty and no small measure of psychological terror to achieve adherence to their strict, unbending commitment to their goal.

The Puritan vision for America presumed a theological stasis in which the inward focus of dogma, combined with threats of horrendous punishment, would prevent desertions. These threats were profoundly supported by the visible threat of the landscape: who could survive in that barbaric wilderness, replete with savage animals and wild men, all utterly Godless? Answering that question was later to engender the frontier spirit.

\section{The intensity of their sorry beliefs}

The power of Puritanism was already in decline when Micliael Wigglesworth (1631-1705) wrote his long poem, The Day of Doom, in 1662 (Pearce, 1967:233297). The title itself possesses no small irony since it refers to Judgement Day, when, as Puritan doctrine would have it, everyone, except God's chosen few, the predestined elect, is doomed to face their justly-deserved punishment. Given the Puritans' obsession with guilt and sin, punishment and suffering, judgement and hell-fire, it is scarcely surprising to find Wigglesworth's poem comprising some 1792 lines of lurid but scrupulously detailed depiction of God taking appropriate action against sinners. Although some readers may be surprised by the virulence of Wigglesworth's poem, they should remember that such imagery may be traced to the Puritan compulsion to resort to fear and violence as legitimate, even holy means of enforcing faith. 
For readers with the stamina to reach Stanza 111 (or Line 881), this is the sort of depiction of humankind that awaits them (1967:264):

Could you find time for vain pastime, for loose licentious mirth?

For fruitless toyes, and fading joyes that perish in the birth?

Had you good leasure for carnal Pleasure, in dayes of health and youth?

And yet no space to seek God's face, and turm to him in truth?

We notice that Wigglesworth regards laughter as "loose" and "licentious" and pastimes as a kind of vanity. Of course, it is possible to find sin everywhere, provided one looks carefully enough. And there can be no doubt that such looseness and licentiousness cannot go unpunished.

In the first four lines of Stanza 143 Wigglesworth (1967:273) assures his readers somewhat ambiguously that God does not take pleasure in crushing or destroying people for its own sake, but $\mathrm{He}$ is compelled to do it for the sake of justice. Nonetheless, there is a pathological prurience in the way Wigglesworth delights in depicting God in action, meting out the barbaric punishments mankind deserves (1967:292-295):

With iron bands they bind their hands, and cursed feet together,

and cast them all, both great and small, into that Lake for ever.

Where day and night, without respite, they wail, and cry, and howl

For tort'ring pain, which they sustain in Body and in Soul.

For day and night, in their despight, their torment's smoak ascendeth.

Their pain and grief have no relief, their anguish never endeth.

There must they ly, and never dy, though dying every day:

There must they dying ever ly, and not consume away.

\section{(...)}

Thus shall they ly, and wail, and cry, tormented, and tormenting 
Their galled hearts with pois'ned darts but now too late repenting.

There let them dwell i'th'Flames of Hell; there leave we them to burn.

Compare this with the insufferable smugness with which the elect, those saved from eternal damnation as part of God's predestined plan, are depicted (in Stanza 219):

The Saints behold with courage bold, and thankful wonderment,

To see all those that were their foes thus sent to punishment:

They do they sing unto their King a Song of Endless Praise:

They praise his Name, and do proclaim that just are all his ways.

One wonders speculatively if Wigglesworth might have seen himself as one of the clect. Be that as it may, his poem provides interesting documentation of the Puritans' compulsive insistence on the obliteration of the individual self to achieve unquestioning submission to control by its theocratic ideology. As Williams (1971:79) observes:

The dreadful and curious thing is that men, despoiled and having nothing, must long for that which they do not have and so, out of the intensity of their emptiness imagining they are full, deceive themselves and all the despoiled of the world into their sorry beliefs.

If Puritanism had not contained the seeds of its own destruction in its rigidity and inflexibility, to say nothing of its intellectual and psychological terrorising of its adherents, rapidly-changing political and economic circumstances in the colonies would have served as a catalyst for its demise. While more compassionate and forgiving doctrines were drawing people away from the Puritan dogma, the advent of the War of Independence focused colonial attention much more intently on political matters, particularly the ways in which Britain was seeking to retain and maintain control over its unruly, troublesome, and insubordinate colonies. Any future vision for America would have to undergo some form of secularisation and politicisation.

Wigglesworth has been dealt with at some length because it is important to understand the brutal, distorted repressive vision the Puritans created for Anerica. Their vision enjoyed a pervasive influence over many decades, and laid the foundation for the visualisation of America as less-than-attractive, a vision 
conflicting notably with the naively buoyant political view of America as a democratic paradise.

\section{Where freedom pursues her generous plans}

In the fourth section of a poem called "Washington Monument by Night", Carl Sandburg (1970:282) writes:

The republic is a dream.

Nothing happens unless first a dream.

The War of Independence was one result of trying to turn that dream into reality.

Originally published in 1787 as The Vision of Columbus, Joel Barlow's long poem re-appeared in 1807 in a revised, longer and more turgid version now called The Columbiad. Barlow's poem also celebrates the political and national aspirations of the newly-independent American "tribe".

As one would expect from a poem written less than 30 years after The Declaration of Independence, Barlow's main subject is democratic republican idealism, and his main stance, affirmation (Barlow, 1809:130):

In these prime settlements thy raptures trace

The germ, the genius of a sapient race,

Predestined here to methodize and mold

New codes of empire to reform the old.

A work so vast a second world required,

By oceans bourn'd, from elder states retired;

Where, uncontaminated, unconfined,

Free contemplation might expand the mind,

To form, fix, prove the well adjusted plan

And base and build the commonwealth of man.

In offering "the commonwealth of man" as a broad vision for the newlyindependent America, Barlow still acknowledges, consciously or unconsciously, the role of predestination in the process of creating something on a grander scale than a city like Zion. Now the vision entails the creation of "new codes of empire" requiring "a second world" as appropriate context. Theological stasis has been replaced by dynamic political processes founded on democratic ideals. Those called on to serve the aspirations of the new state are described (Barlow, 1809:152) as "elected sires" who "assume the cares of state". These men are ideally suited to the task not simply because they have been "Nursed in equality" and are "to freedom bred" but also because they possess reason and flair:

All rights that Britons know they here transfuse,

Their sense invigorate and expand their views, 
Dare every height of human soul to scan,

Find, fathom, scope the moral breadth of man,

Learn how his social powers may still dilate

And tone their tension to a stronger state.

The Puritan idea of the elect persists, although the criteria for being chosen have ceased to be theologically based and in God's hands; the process is now secular, political and in the hands of the electorate.

These "elected sires" were working for democratic rather than religious ideals (Barlow, 1809:281):

Based on its rock of right your empire lies,

On walls of wisdom let the fabric rise;

Preserve your principles, their force unfold,

Let nations prove them and let kings behold,

EQUALITY, your first firm-grounded stand;

Then FREE ELECTION; then your FEDERAL BAND;

This holy Triad should forever shine

The great compendium of all rights divine,

Creed of all schools, whence youth by millions draw

Their themes of right, their decalogues of law;

Till men shall wonder (in these codes enured)

How wars were made, how tyrants were endured.

Paradoxically, the democratic republican dream presumed the imposition of white Eurocentric values and ideals on the continent's Native American and African American inhabitants.

Barlow's depiction (1809:42) of some of the Native Americans perpetuates, in more specifically gruesome detail, stereotypical views of "Crowds of war painted chiefs, athirst for gore" who "( 1 )rack the mute foe", capture them, torture them, butcher them, "suck the warm veins and grime their cheeks with blood". In almost two centuries, little had changed in perceptions about the indigenous peoples, generally speaking.

Not all tribes were violent, however. There were others there who lived in "settled hamlets" and "corn-clad vales" where they could "a happier state attest" (Barlow, 1809:42). Nonetheless, there was a profound arrogance and an inherent anomaly in affluent white male presumptions about Eurocentric values and the relevance of this vision for Native and African Americans.

At this point, it is worth turning, albeit briefly, to Philip Freneau's poem entitled Prctures of Columbus which appeared just one year after Barlow's Visions of 
Columbus. In Picture XIV, Freneau (1958:341-342) depicts Columbus musing on pre-colonial America:

Sweet sylvan scenes of innocence and ease,

How calm and joyous pass the seasons here!

No splendid towns or spiry turrets rise,

No lordly places - no tyrant kings

Enact hard laws to crush fair freedom here;

No gloomy jails to shut up wretched men;

All, all are free! - here God and nature reign;

Their works unsullied by the hands of men -

In the final Picture, No XVIII, Columbus reflects on his fate, living out his last years in disgrace with the Court of Spain, and proffers a small vision for America (Freneau, 1958:346):

Yet, in this joyless gloom while I repose,

Some comfort will attend my pensive shade,

When memory paints, and golden fancy shows

My toils rewarded, and my woes repaid;

When empires rise where lonely forests grew,

Where Freedom shall her generous plans pursue.

Columbus's vision interestingly fills America's virgin space with a combination of the Puritans' urban urge and America's new but naive ideology of democratic freedom, a freedom which symbolically embodies in political terms the literal freedom of the American continent. The fine blend of idyllic pastoralism and democratic naivety Freneau offers scarcely presents even an approximation of American reality, however.

\section{Thou land of blood, and crime, and wrong}

Writing as late as 1958 about Jefferson's contribution to The Declaration of Independence, Edwin H. Cady (1958:13) could still argue: “... it has not always been appreciated that Jefferson did exactly the right thing in appealing to what everybody thought."

"Everybody" here excludes Native and African Americans as well as women. The voice of dissent, one which would give a realistic rather than idealistic view of America, is crucial to an understanding of the role of vision in the American long poem of the nineteenth century. That voice comes in the form of James $M$. Whitfield and his poem, America, published in 1853. This poem (Robinson, 1973:40-43) is crucial historically for helping to correct American literary history's almost exclusively white orientation and perspectives. Because it is so little known and difficult to access, a substantial extract seems appropriate: 
America, it is of thee,

Thou boasted land of liberty, -

It is to thee I raise my song,

Thou land of blood, and crime, and wrong.

It is to thee, my native land,

From which has issued many a band

To tear the black man from his soil,

And force him here to delve and toil;

Chained on your blood-bemoistened sod,

Cringing beneath a tyrant's rod,

Stripped of those rights which Nature's God

Bequeathed to a petty tyrant's nod,

Because he wears a paler face.

Was it for this that freedom's fires

Were kindled by your patriot's sires?

Was it for this they shed their blood,

On hill and plain, on field and flood?

Was it for this that wealth and life

Were staked upon that dreadful strife,

Which drenched this land for seven long years

With blood of men, and women's tears?

Whitfield argues that the War of Independence - what he calls "that desperate strife" - has not resulted in a land where "the inherent rights of man" are respected and revered but in a land where "the framers of a code" - these are the same men Barlow refers to as "elected sires" - have produced "unjust, oppressive laws" that would "disgrace the fiends of hell!" Whitfield's vision of America harks back to Wigglesworth's pathological vision of hell in The Day of Doom, but Whitfield's hell finds its real existence in the limbo between an idealistic democratic vision and a brutal democratic reality.

The anger Whitfield expresses at the failure of the much-vaunted democratic vision engenders another vision, one which is essentially a re-articulation of the original secular aspirations of the early colonists (Robinson, 1973:43):

But in the sacred name of peace,

Of justice, virtue, love, and truth,

We pray, and never mean to cease,

Till weak old age and fiery youth

In freedom's cause their voices raise,

And burst the bonds of every slave;

Till, north and south, east and west,

The wrongs we bear shall be redressed.

The bases of Whitficld's vision - peace, justice, virtue, love, and truth - differ substantially, of course, from the basic commitments made to American citizens 
in The Declaration of Independence which affirmed equality and the inalienable rights to Life, Liberty and the pursuit of Happiness.

African Americans eventually got the constitutional right to vote by the Fifteenth Amendment in 1870, almost 100 years after The Declaration of Independence. They were, however, disenfranchised in the south generally between 1877 and 1904 by the nature of voting requirements and practices. Women were given the vote in 1920 by virtue of the Nineteenth Amendment but Native Americans gained citizenship only in 1924.

One of the major problems of The Declaration of Independence lies in the fact that many inhabitants of America perceived it as a statement of a vision for America, and consequently failed to see it as a magnificent piece of propaganda.

\section{The greatness of love and democracy}

In some ways, Whitman's Leaves of Grass may be said to constitute magnificent propaganda of another sort. It is here perhaps more than in any other American long poem that the paradoxicality of the American vision and American ideology is comprehensively explored. The poet himself explains in his characteristic manner (Whitman, 1982:569):

Brain of the New World, what a task is thine,

To formulate the Modern - out of the peerless grandeur of the modern,

Out of thyself, comprising science, to recast poems, churches, art

(Recast, may-be discard them, end them - may-be their work is done, who knows?)

By vision, hand, conception, on the background of the mighty past, the dead,

To limn with absolute faith the mighty living present.

In the Preface to the first 1855 edition of the book, Whitman, with typical bravado and flamboyance, states (see Kaplan, 1982:5): "The United States themselves are essentially the greatest poem". In trying to record the poem which was the United States, Whitman is compelled to create a vision for a nation observed through one pair of eyes, missing as much as they see.

A second troublesome aspect of Whitman's work resides in the paradoxical nature of the vision he articulates at the very beginning of Leaves of Grass $(1982: 165)$ : 
One's-Self I sing, a simple, separate person,

And yet utter the word Democratic, the word En-

Masse.

The paradox of the individual in the crowd and the crowd comprising unique individuals remains unresolved as a result of Whitman's optimistic naivety, a naivety which is almost as idyllically untainted by reality as Barlow's was. Where Barlow affirmed Equality, Free Elections and Federal Bands, Whitman (1982:181) proclaims the three "greatnesses" all should enjoy equally:

My comrade!

For you to share with me two greatnesses, and a

third one rising inclusive and more

resplendent,

The greatness of Love and Democracy, and the greatness of Religion.

It is worth noting that religion still constitutes part of the American vision, albeit in more attractive terms than in The Day of Doom.

The "hideous and desolate wilderness" of Puritan reality, together with their vision of recreating the City of Zion, was metamorphosed in Barlow's poem into "these prime settlements". Whitman's vision sustains the idea of the "new city", no longer Puritan but Quaker, as we read in "I Dream'd in a Dream" (see Kaplan, 1982:284):

I dream'd in a dream I saw a city invincible to the attacks of the whole of the rest of the earth,

I dream'd that was the new city of Friends,

Nothing was greater there than the quality of robust love, it led the rest,

It was seen every hour in the actions of the men of that city,

And in all their looks and words.

The rational qualities of Barlow's people within their prime settlements are here imbued with a Romantic freedom of spirit and "the quality of robust love" which allows Whitman to draw attention not only to their rational behaviour (as Barlow did) but also to their appearance, words, and deeds.

In Whitman's vision, the world's major philosophical schools from the Greeks through Christianity to the "Germanic systems" of Kant, Schelling and Hegel are underpinned by:

The dear love of man for his comrade, the attraction of friend to friends, 
Of the well-married husband and wife, of children

and parents,

Of city for city and land for land

(Whitman, 1982:275).

In Whitman's vision, there appear to be no badly-married couples, no enemies, no generational problems; in fact, nothing but love between all people. But, implicitly at least, Whitman tends to generalise at the level of the category and so lose the individual. Indeed, Whitman's celebrations of the "institution of the dear love of comrades", as he calls it (1982:281), actually and ironically ignore the uniqueness of individuals and their complex diversity.

Brotherly love and comradeship, democracy and America's mission in the world were put to the severest kind of test for more than four years, beginning in 1861 . The Civil War was a conflict of cultures, between the quite particularistic vision the South had of itself and the cosmopolitan idealism of the nation.

For Whitman, it was a chance for the American nation to show its mettle to the world by bringing its "joys and prosperity" into conflict with "direst fate" so as "to learn from crises of anguish" (Whitman, 1982:445). It would seem that Whitman believes that such conflict will ultimately yield a vision of even greater clarity which will "show to the world what your children en-masse really are".

There is a certain ironic quaintness in the way Whitman speaks of America and its "children en-masse" at a time when the whole fabric of democracy was being challenged and threatened by other individuals, equally en-masse, choosing to dissent from national ideals and ideologies, to advocate and pursue a particularistic vision of their own.

Indeed, even Whitman's idealistic vision of America required some control over the anarchy inherent in unbridled individualism (Whitman, 1982:597):

I see Freedom, completely arm'd and victorious and very haughty, with Law on one side and Peace on the other,

A stupendous trio all issuing forth against the idea of caste.

There is a nice paradox inherent in the figure of Freedom armed and ready to compel or coerce dissenters. It is the same paradox we find in these, the opening lines of the third section of "Rise O Days from your Fathomless Deeps" (Whitman, 1982:428), taken from the Civil War text, Drum-Taps:

Thunder on! stride on, Democracy strike with vengeful stroke! 
And do you rise higher than ever yet $\mathrm{O}$ days, $\mathrm{O}$ cities!

Crash heavier, heavier yet $\mathrm{O}$ storms! you have done me good.

The poet himself was aware of the paradoxical nature of his vision and its expression. In "A Song for Occupations" (Whitman, 1982:360), for example, he speaks of: "Strange and hard that paradox true I give". It is worth speculating that, in embedding his vision for America in paradoxicality, Whitman was intuitively aware of a truth that was only later to find its expression in the words of C.G. Jung (see Jacobi, 1971:356-357):

Oddly enough the paradox is one of our most valuable spiritual possessions, while uniformity of meaning is a sign of weakness ... only the paradox come anywhere near to comprehending the fullness of life.

And if his vision of America and his recording of it does contain paradoxes and contradictions, Whitman (1982:246) acknowledges them with a disarming ease :

Do I contradict myself?

Very well then I contradict myself,

(I am large, I contain multitudes.)

Although Whitman may have been able to relish the high levels of ambiguity inherent in his vision of America, others found that such ambiguities and contradictions led to another, bleaker vision.

\section{The lost America of love}

By the middle of the twentieth century, madness and insanity were no longer illnesses; they had become symptoms. Besides, the distinction between sanity and madness - or even nonnality and abnormality - had become much more difficult to make and had become increasingly contentious.

Perceived early in the century as a sterile wasteland inhabited by the living dead, the city assumed more terrifying dimensions until the individual's main escape route lay, ironically, through drugs, suicide, madness and the mental institution.

The prurient phantasmagoria of Wigglesworth's Day of Doom finds its twentiethcentury counterpart in Allen Ginsberg's Howl, originally published in 1956, a poem whose title evokes Whitman's "barbaric yawp" of more than a century earlier but adds to it a good deal of pain and fearful overtones of brutalised man. God has been replaced by an equally omnipresent, omnipotent bureaucracy seeking to reduce individuality to numbers and functions operating within a simplistic version of dualism. The "normality" of the system drives individuals to 
madness while the psychiatric system designed to help them return to the socalled "normal" world is perceived as even more bizarre and dangerous than madness itself. Ken Kesey was to reveal this when he published his novel about a mental institution, One Flew Over the Cuckoo's Nest, in 1962.

Neither the Puritans' vision of the new City of Zion nor Barlow's "prime settlements" nor Whitman's "new city of Friends" nor Eliot's meaningless "Wasteland" reveals the frenetic and hysterical existence of those inhabiting the nightmare landscape of the twentieth-century city where, Ginsberg asserts, "the best minds of my generation" have been "destroyed by madness" (Ginsberg, 1985:1946).

Using Whitman's accretive technique, Ginsberg catalogues the full repugnance of the modern world in fine, precise yet sordid detail and overwhelming technicolour, creating scenes reminiscent of Hieronymus Bosch at his most savage and shocking. The inhabitants of Ginsberg's city have become:

a lost battalion of platonic conversationalists jumping down the stoops off fire escapes off windowsills off Empire State out of the moon

yacketyyakking screaming vomiting whispering facts and memories and anecdotes and eyeball kicks and shock of hospitais and jails and wars

whole intellects disgorged in total recall for seven days and nights with brilliant eyes, meat for the Synagogue cast on the pavement,

who vanished into nowhere Zen New Jersey leaving a trail of ambitious picture postcards of Atlantic City Hall (Ginsberg, 1985: 1947).

Ultimately, it is the fate of this "lost battalion" to suffer having "the absolute hearts of the poem of life butchered out of their own bodies". Forms of violence seem to have changed little since the mutilations inflicted by the Puritans, and even the promises of Zen seem to have failed.

If the first section of Howl is given over to the fate of individuals in America, the second section examines what America has become through its symbolic worship of Moloch, the god to whom children were sacrificed. Here is a brief extract (Ginsberg, 1985:1952):

Moloch whose eyes are a thousand blind windows! Moloch whose skyscrapers stand in the long streets like endless Jehovahs! Moloch whose factories dream and croak in the fog! Moloch whose smokestacks and antennae crown the cities! 
Moloch whose love is endless oil and stone! Moloch whose soul is electricity and banks! Moloch whose poverty is the specter of genius! Moloch whose fate is a cloud of sexless hydrogen! Moloch whose name is the Mind!

In reformulating nineteenth-century Romantic criticisms of industrialisation, the pursuit of wealth and the depredations of materialism, Ginsberg employs twentieth-century images to establish the nightmarish dimensions of this vision. The vicious, revengeful yet human God of Puritanism has evolved into a dehumanised, technological, chthonic daemon. Fear remains its greatest power.

The third section of Howl focuses on the figure of Carl Solomon, one of the poet's friends and fellow patients in 1949, described by Ginsberg as "madder than I am", and, at that time, confined in Rockland, a psychiatric hospital (Ginsberg, 1985:1953-1954):

I'm with you in Rockland where you bang on the catatonic piano the soul is innocent and immortal it should never die ungodly in an armed madhouse

I'm with you in Rockland where fifty more shocks will never return your soul to its body again from its pilgrimage to a cross in the void.

$(\ldots$.

I'm with you in Rockland in my dreams you walk dripping from a sea-journey on the highway across America in tears to the door of my cottage in the Western night

Ginsberg (1985:1954) visualises the nation as "the United States that coughs all night and will not let us sleep". It is a country where the mentally ill are brutalised with electro-convulsive therapy to compel them back into the "normality" which originally drove them crazy rather than allow them to pursue their madness and celebrate their visionary potential. America has become a country where dissenting souls who reject the abnormality of "normality" may find themselves confined to a madhouse where armed guards prevent anyone from escaping programmes designed to deprive such souls of their uniqueness until they are "normal" enough to be returned to society. This is the obverse side of "the lost America of love". 
The individual and the self are consistently "lost"; in the beginning, in submission to various creeds: religious and political philosophies; later, in egodisintegration and psychotic collapse as they dare to oppose the depredations of the bureaucratic system, the pervasive anonymity of democracy, and the peripheralisation of the individual as society's dominant "norms" prevail and more people become more abnormally "normal" at the expense of their selves and, concomitantly, their sanity.

\section{A paradiso terrestre or the air-conditioned nightmare}

When the Puritans landed on the eastern seaboard of the continent, they were immediate struck and yet inspired by its Biblical parallels. Just after the middle of the seventeenth century, Michael Wigglesworth created his ghastly scenario for the Day of Doom. By the middle of the twentieth century, Allen Ginsberg reports that the American dream has turned into something far more horrendous than Henry Miller's "air-conditioned nightmare". The Puritan vision of Hell has become a reality where madness, death and suicide are preferable to the societally condoned and bureaucratically reinforced stasis of "normality". The vision has shifted from theocracy through democracy to a bureaucracy which suggests a final formulation as apocalypse.

\section{References}

Barlow, Joel. 1809. The Columbiad. New York : Mulligan.

Bradford, William. 1985. Of Plymouth Plantation. In: McMichale, George (ed.) Concise Anthology of American Literature. London : MacMillan. p. 25-39

Cady, Edwin H 1958 Literature of the Early Republic. New York/Toronto : Rinehart. p. $340-347$.

Freneau, Phillip. 1958 Pictures of Columbus. In: Cady, Edwin H. (ed.) Literature of the Early Republic. New York/Toronto : Rinehart. p. 340-347.

Ginsberg, Allen 1985. Howl. In: McMichael, George (ed.) Concise Anthology of American Literature. London: Macmillan. p 1946-1954.

Higginson, Francis. 1965. In: Boorstin, Daniel J. The Americans, Volume 1. Harmondsworth, Middlesex : Penguin Books p. 17.

Jacobi, Joland (ed.) 1971. C.G. Jung: Psychological Reflections. London: Routledge \& Kegan Paul. p. 356-357.

Kaplan, Justin (ed) 1982. Walt Whitman: Complete Poetry and Collected Prose. New York : The Library of America

Kesey, Ken. 1962. One Flew over the Cuckoo's Nest. New York: Viking.

Robinson, William H. (ed) 1973. Early Black American Poets. Dubuque, lowa : Brown p. $40-43$.

Sandburg, Carl. 1970. Complete Poems. New York: Harcourt Brace Jovanovich.

Tillam, Thomas 1968. In: Waggoner, Hyatt H. American Poets from the Puritans to the Present. Boston: Houghton Mifflin p 15.

Whitfield, James M 1971. America. In: Robinson, William H (ed) Farly Black American Poets. Dubuque, Iowa : Brown p 40-43. 
Whitman, W. 1982. In: Kaplan, Justin (ed.) Walt Whitman: Complete Poetry and Collected Prose. New York: The Library of America. p. 165-672.

Wigglesworth, Michael 1967. The Day of Doom. In: Pearce, R.H. Colonial American Writing. New York : Rinehart \& Co. p. 233-297.

Williams, William Carlos. 1971. In the American Grain. Harmondsworth, Middlesex Penguin Books. 
